\title{
8
}

\section{URBAN EVENTS AND THE SOUL OF THE CITY}

\section{The Poetic Political Tripartition of Urban Form}

\author{
Ildebrando Clemente
}

The analogy between the concept of soul and the idea of city is established in Book IV of the Republic. An analogy that historian and philologist Nicole Loraux sees in her famous publication, The Divided City, as a true paradigm for understanding the essence of Greek cities, Athens first and foremost, since it leads us "to give the city a memory that resembles that of the individual, since they (the Greeks), perhaps more than anything else, conceived the analogy between the city and the individual as political" (Loraux 2006, 141). Keeping the French historian's assertion open, we could say, in other words, that the essence of the Greek city is expressed in the link between city and citizen, between place and individual.

Now, projected into the space of collective values, the signs of this invisible link, the signs of the soul, are also expressed through the forms and spaces of the city and can be investigated by looking at the urban events. It comes as no surprise, therefore, that, in the 1960s, in his efforts to outline a rational theory of urban design, Aldo Rossi defined Athens as "the first clear idea of the science of urban events; it is the passage from nature to culture, and this passage, which is part and parcel of urban events, is offered to us by legend" (Rossi 1991, 193). According to Rossi, Athens is a clear idea of a city because it develops from the inside toward the outside according to a tripartite layout in which the primary generating elements of the urban form are articulated and recognizable: the temple, the organs of political and social life consisting of the buildings connected with collective activities, and so on; these structures are surrounded by the dwellings of the urban and rural communities. Athens is a clear idea of a city and yet, Rossi continues, it is also an unachievable urban idea: a city that "remains as the purest experience of humanity, in conditions that can never return" (Rossi 1991, 200). The conditions that can never return, to which Rossi probably alludes, are those expressed in the link between city and territory and which, in turn, are reflected in the link between city and citizen.

The feeling of the loss, in our time, of this original link between man and place by the universal Mobilmachung drives people, consciously or unconsciously, to live together but without being part of a community. We can ask ourselves: does the loss of the original link between place and individual mean the loss of the city's soul? And again: is it possible to 
think of a city, an image of a city, without a common origin among its citizens? This is the decisive and indirect question that emerges from the history of Athens and into which Aldo Rossi's reasoning ventures. In my opinion, to answer this question, Aldo Rossi calls upon the idea of the soul of the city. L'âme de la cité which, according to Rossi, unfolds before us in the figure of the collective memory of people. Rossi's idea of the city as a locus of the collective memory is an extension of Maurice Halbwachs's theories, according to which the city acts as a mirror that somehow reflects the soul of its citizens in the composition of the soul of the city, animating its ethical sense through remembrance (Halbwachs 2001). With the exercise of remembrance, every citizen within the city is stimulated to know himself or herself, his or her innermost soul. And this ethical self-knowledge represents the authentic source of his or her thoughts and actions (Figure 8.1).

As has been pointed out by many scholars of Plato, including Erwin Rohde, the link between soul and city is expressed not only through a structural analogy but also through one of a dynamic nature. In the structural analogy, it is possible to see how both the structure of the city and the structure of the human soul are divided and articulated in equal parts. In the dynamic analogy, however, it is possible to see that the form of the city acts like a soul and, in turn, the human soul acts like a city (Rohde 2006). As far as the structural analogy is concerned, it is worth remembering that Plato, again in Book IV, describes the soul as articulated in three parts: reason, which resides in the head; spirit, located in the heart; and, last, appetite, located in the gut, where irrational appetites originate. Human behavior can be

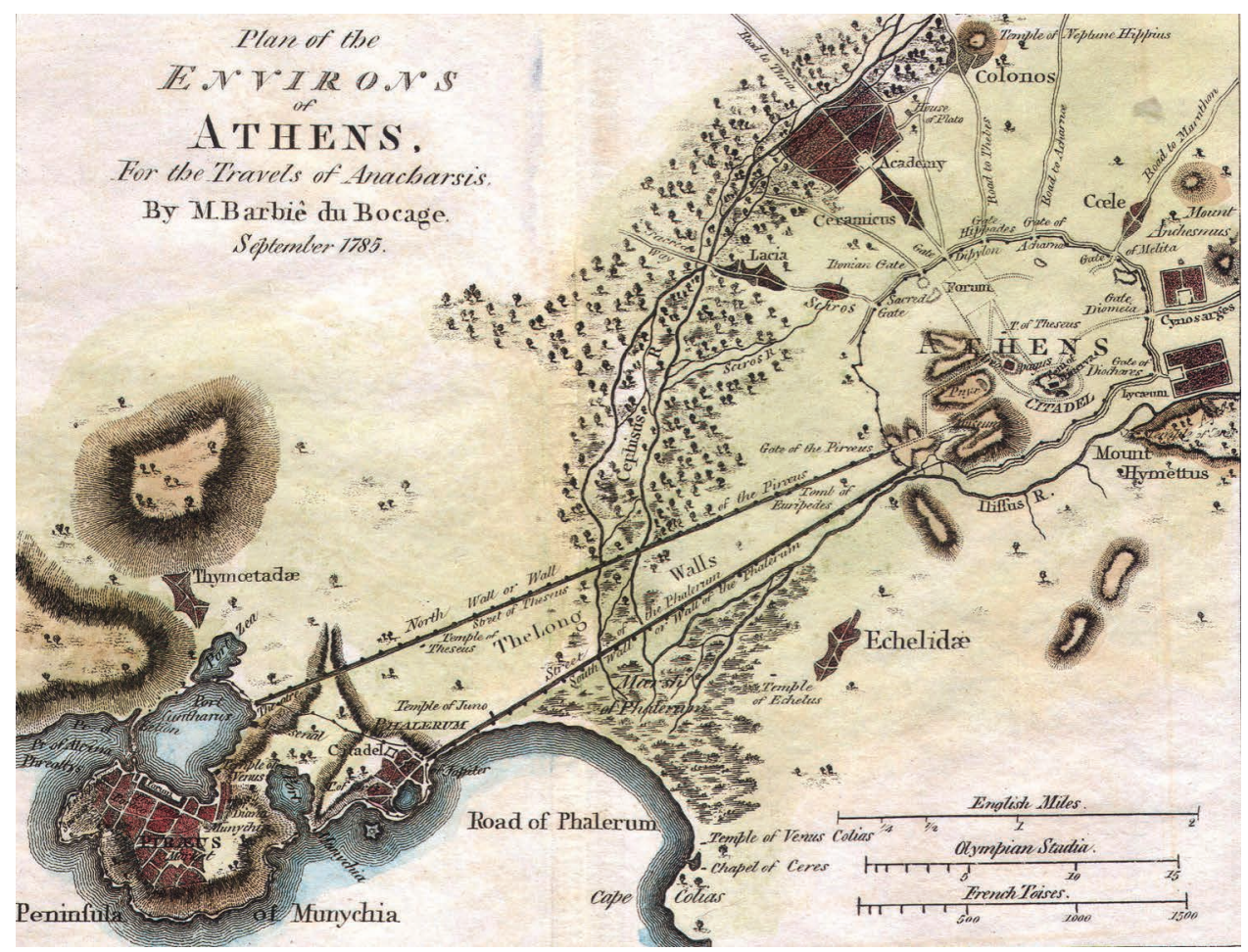

FIGURE 8.1 City plan of Athens in Ancient Greece, drawn by M. Barbie de Bocage, 1784. 
analyzed, understood, and explained, precisely on the basis of the varying degree to which the three parts of the soul combine with each other, generating in people a different way of facing reality (Republic 436a-445e). In the same way, Plato imagines a polis founded on a tripartite order in which he sees the top represented by the philosophers, capable of showing the right way and acting in view of achieving the common good; then come the guardians, the legal and military class, whose job is to protect the city, its resources and its wealth; and, last, the working people, farmers, shepherds, and tradesmen who provide sustenance and food for the city.

This idea of organization of the polis is the result of a long historical process. When Plato proposed his idea of a tripartite city-state, the transition from a mythical vision of the organization of the earth to a geometric and rational conception was already underway in Greece, as shown by Jean-Pierre Vernant (2001). The mythical image of the link between man and earth was centered on the vision of a space divided into three levels. The space of the immortal gods and Zeus was the first level, the second level was that occupied by men, and the third level was associated with death and the gods of the underworld. On an ideological level, however, the transition from the mythical space of the temple-city to the rationally subdivided space of the city-state is encompassed entirely within Hippodamus' idea of the city. The famous architect from Miletus had outlined his ideas of the city-state in a treatise, On the Constitution, of which traces remain in Aristotle's Politics (Politics 1267b, 22-37=VII, 1-3). Politics summarizes the main aspects of Hippodamus' reflections, which, according to the Stagirite, are contained in the concept of division, the invention of the subdivision of the city into parts. Aristotle's notes reveal Hippodamus' predilection for trichotomy, and the Milesian suggests an ideal city divided into three classes - tradesmen, farmers, and warriors - organized in a territory divided into three sectors: sacred land, reserved for the gods; public land, reserved for warriors; private land, reserved for farmers. The three classes are united on a strictly political level, forming a single demos that elects its magistrates (Greco 2018; Figure 8.2).

The topography of the city of Athens can also be read as a tripartite form. The highest part of the city is occupied by the Acropolis. This area was originally intended for the construction of the palaces of the rulers of the city, and only later did it become the site of the places of worship and temples. Below and around the Acropolis is the astù, the lower part of the city, divided into several interconnected parts, containing buildings and public spaces, with the agora in the center. The lower part of the city was surrounded by the chora, a large area of farmland and pastures, necessary for the city's subsistence and for the provision of essential foodstuffs (Morachiello 2003).

It is important to remember that Plato arrives at the geometric-political idea of the tripartition of the soul and the idea of the polis by rewriting two ancient and persistent events that were part of the culture of the time. On the one hand, he reinvents the Pythagorean tradition, sustained by Hippodamus, which envisaged the subdivision of the soul of the world into three parts, located respectively in the head, the heart, and the navel of man (Macchioro 2014). On the other hand, by rewriting the traditional Indo-European political tripartition, Plato replaces this ternary structure, in which the priests were in charge of the city's destiny, with the figure of the philosopher.

The idea of a social and political order and of the occupation of geographical space based on a tripartite articulation is an archaic idea. Georges Dumézil highlighted the debt of European culture, and also of Plato, to the Indo-European heritage with regard to the 


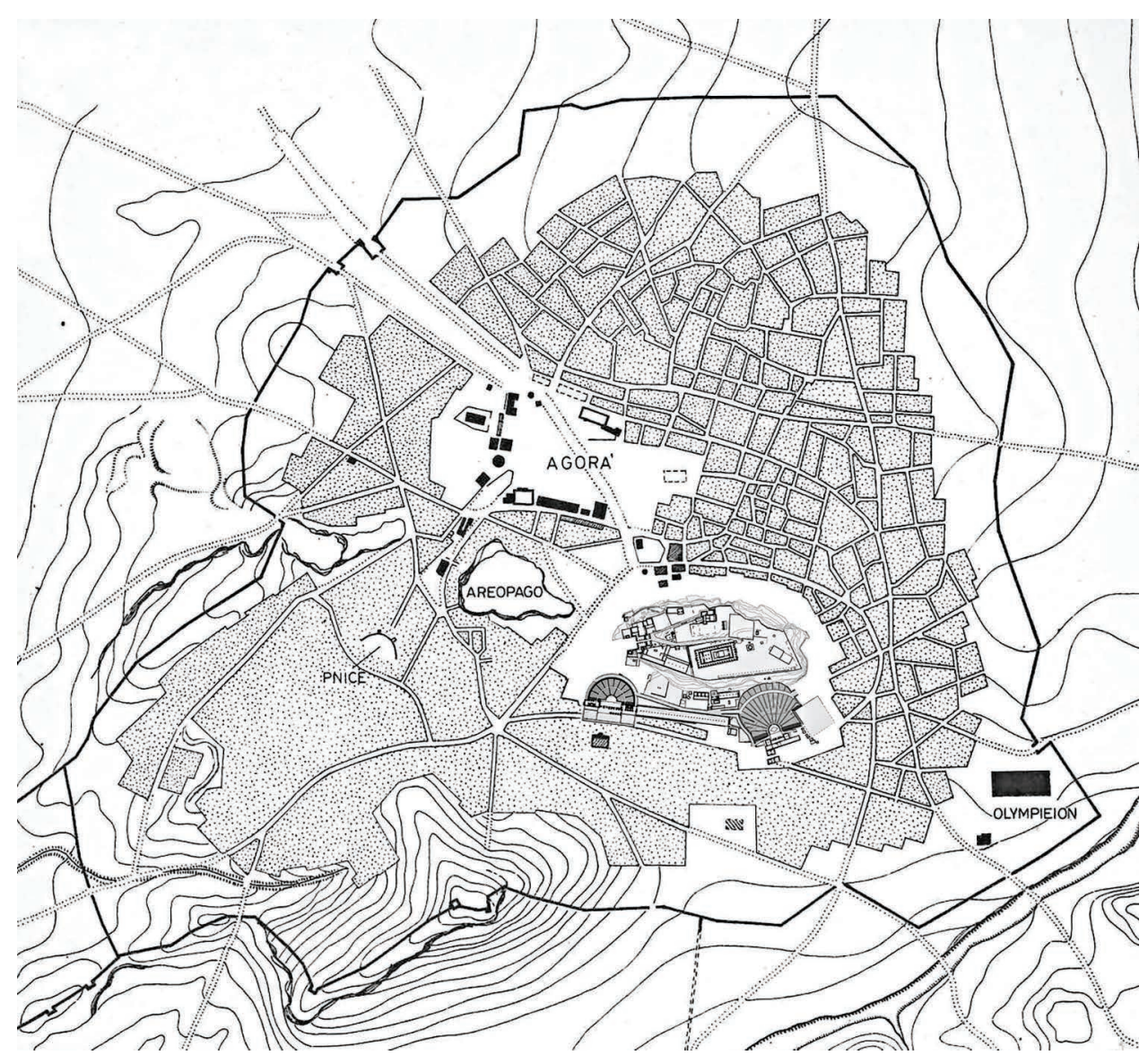

FIGURE 8.2 City plan of Athens in Ancient Greece. In evidence, Acropolis, Asty-Agorà, Chora.

invention of the tripartite community structure (Dumézil 2017, 25). The tripartite ideology of the Indo-Europeans envisaged an isomorphism between a trifunctional theology and a social tripartition. To achieve this mirroring, theology divided the divine world into gods of sovereignty, gods of strength, and gods of fertility, which corresponded to a social tripartition into priests, warriors, and farmers-breeders. Each of these groups was assigned a physical location: palaces and temples for the priests, arsenals and courts for the warriors, villages for the others. In Dumézil's anthropological vision, tripartition is a force that has been at work in European history from the very beginning. Like an archaeological trace, the force of tripartition continues relentlessly to operate in the subsoil of European culture, rather like a child who continues to develop and suddenly emerges as an adult, at least according to the theories of psychoanalysis (Freud 1977, Halbwachs 2001, 94-101; Figure 8.3).

Le Corbusier's urban theory also contains the idea of a tripartite functional order in which something both economic and psychological is present. The city is not something that can ever be considered complete, it is always evolving, and this is how we can understand Le Corbusier's words: "Future cities are usually ancient cities" (Le Corbusier 1980, 79). In Le Corbusier's vision, too, the invisible and problematic link between man 


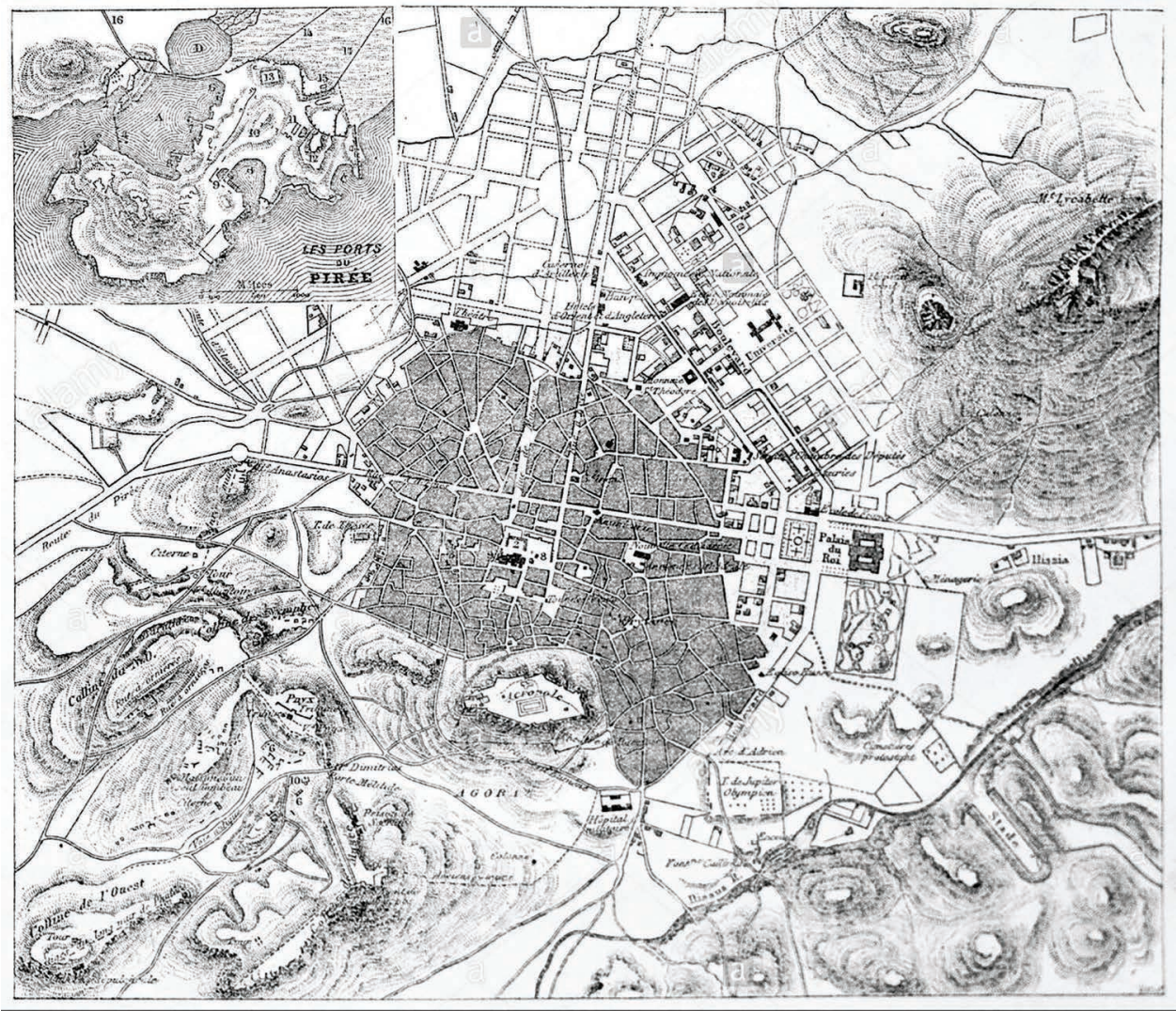

FIGURE 8.3 City plan of Athens, 1862.

and the city is clarified by the figure of the soul. The life of a city, wrote Le Corbusier, "is a continuous event that takes place over the centuries with material works, layouts or constructions, which give it its own personality and from which its soul emanates little by little" (Le Corbusier 2014, 113). Le Corbusier uses tripartition several times in his writings to illustrate his urban theory. In the Athens Charter, the three functions of the city are articulated in extreme synthesis. The three basic functions are: “1) living, 2) working, 3) recreation. The matters proper to the city are: a) occupation of the land; b) organisation of traffic; c) legislation" (Le Corbusier 2014, 147).

The French economist Thomas Piketty (Piketty 2020, 74-740) has shown how the invention of the ternary structure has been used throughout history, either to legitimize or delegitimize the relationship between a dominant system of government and social inequalities. Nevertheless, according to Piketty, despite their ability to adapt and transform preexisting needs and conflicts into new social and urban configurations, trifunctional arrangements have never been able to completely undo the inequalities and injustices induced by the ruling classes, which inevitably emerge within it. However, despite all the imperfections, functional tripartitions are still, as also suggested by Émile Benveniste, an effective way to prefigure, in ideological terms, the general advantages of a society as a whole (Benveniste 2001, 215-225; Figure 8.4). 


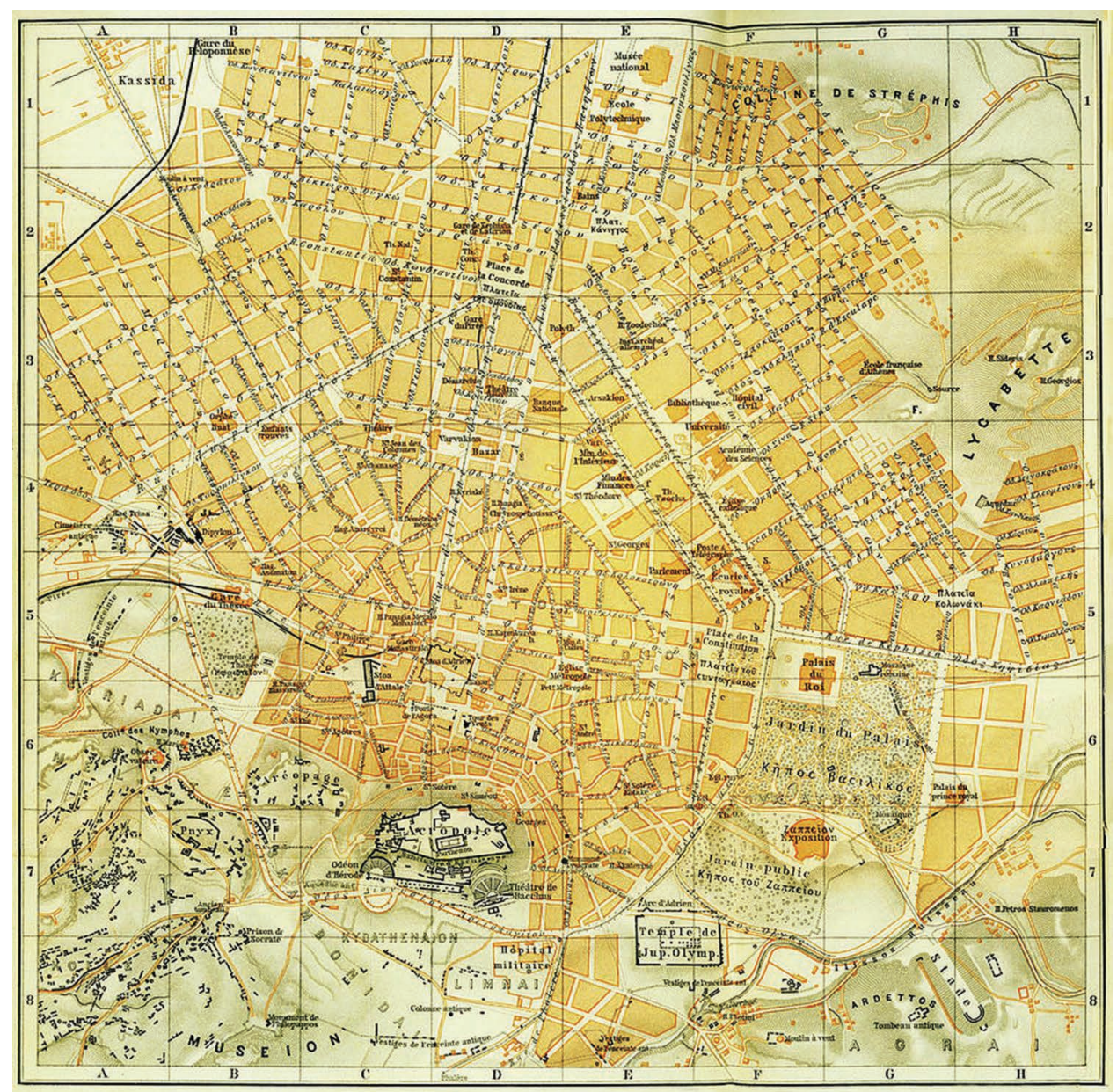

FIGURE 8.4 City plan of Athens, 1894.

Plato's tripartite strategy also aimed to overcome inequalities and conflicts by introducing the medicine of the soul into the body of the city - and into the body of the citizen (Patočka 2019). We know that the buildings and temples of the acropolis were originally assigned the task of guaranteeing the mythical-ritual memories of the polis and of upholding the peace covenants between the different factions, avoiding stasis and thereby guaranteeing the unity and social cohesion of the different groups that made up the polis. We also know that with the growth of the city of Athens and the formation of new classes, especially between the 4th and 5th centuries, the cohesion and harmony of the city became increasingly difficult. From this moment onwards, the polis became increasingly consolidated as an aggregate that was not founded on a "revelatory order" but rose as a reality based on a rationally re-elaborated and motivated "democratic order." A reality that is constantly called upon to re-discuss and re-think its assumptions and its governing directives. The vibrant heart of the pursuit of unity thus shifts from the acropolis to the agora, which becomes the center for collective initiatives and the interests of the daily life of the people. In this way, the symbolic 
and political unity, somehow the deep soul of the city, inscribed in the space of the acropolis, is divided into two antagonistic poles. It is precisely in this division that the medicine of the soul is called upon to operate, even with collective oblivion and removal if necessary.

As shown by Nicole Loraux, this separation between the place of tradition and the gods, and the place of the individual needs and anxieties of everyday life, slowly penetrates the collective unconscious of the polis (Loraux 2006, 121-152). It is easy to see that this division is felt in the urban space as well as in the hearts and minds of the people. With this division, the people suffer the ethical, civil, and religious fragmentation of their inner soul. The people now see two forces to be entrusted with their destiny. How can the division in progress be reconciled? The uniqueness of Greek genius, as shown by Eric Robertson Dodds, was that it did not neglect this psycho-physical conflictual reality but incorporated it and institutionalized it in an official form in a new space: the theatre (Dodds 2003). In the city-state, the theatre is configured as the third place of the dark potential of the human and collective soul. The people see theatre as a sort of bridge over the huge gap between the mythicalritual space of the gods and the political-economic space of man. A bridge which, thanks to the imagination, reunites the separated parts and rebuilds the link between men and the local gods and the forces of nature in a new and poetic form.

In other words, the medicine of the soul, called upon to use its rational component to heal the irrational conflicts that arise in the body of the city, sheds light on the importance of imaginative solutions for the city's destiny. The soul is an image-based reality, the quintessence of the dream world. And imaginative solutions are essential for addressing the conflicting and heterogeneous nature of the city. The soul is a way of fabricating a myth. Even Plato's Republic ends not with the exaltation of reason but with the surreal tale of the legend of $\operatorname{Er}$ (Figure 8.5).

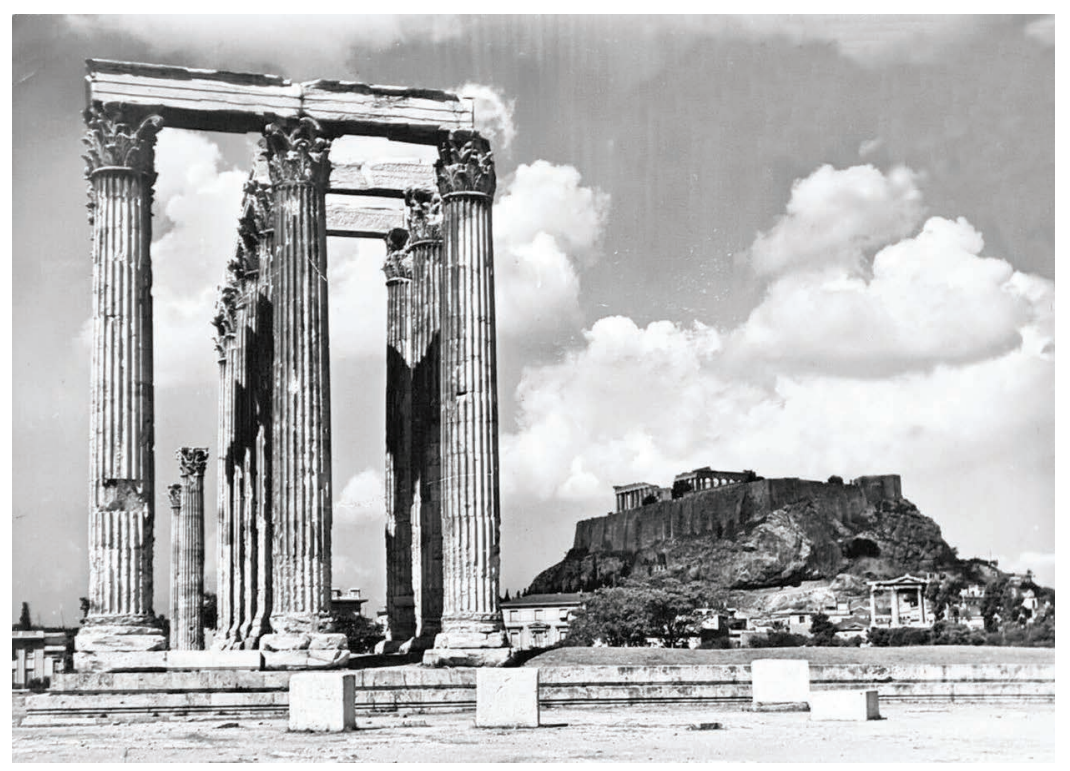

FIGURE 8.5 View of the Acropolis from the south. 
I believe, as already mentioned, that the urban theory developed by Aldo Rossi in his famous book L'architettura della città (The Architecture of the City) can also be traced back to the ternary spirit, simultaneously ideal and imperfect, and its implications for the human condition. I am convinced that both urban analysis and the theory of the city divided into parts are nothing more than the invention of a myth. A myth elaborated by Rossi at a particular moment in history in response to the risk of the loss of identity and the role of architecture in the city. A myth suggested to counter the unscrupulousness and arrogance of the faceless city of capitalist speculation. A myth conceived, like every other myth, to defend differences. In this case, to defend the memory and the heterogeneous characteristics of urban events. Rossi's interest in the urban psychology of tripartition includes his desire to develop the concept of locus on the basis of certain studies by religious historian Kàroly Kerényi, who, in the introduction to the text Prolegomeni allo studio scientifico della mitologia (Prolegomena to the Scientific Study of Mythology), identifies the tripartition of cities and buildings as one of the main reasons for the foundation of the urban space and ancient architecture (Rossi 1991, 310-311, Kerènyi 2007, 34-35).

The importance of tripartition as a spatial configuration pattern of the city and architecture represents a common formula in the conception of ancient architecture. As shown by James Ackerman, Palladio's architectural principles based on the regeneration of antiquity and the rationality of composition also rely on the continuous reinvention of the triadic compositional system that alludes to the unattainable origins of architecture (Ackerman 1972). In continuity with the ancient experience, Rossi too tackles each compositional issue by resorting to triadic structures, elevating them, however, from the organic, rational, and political principles that trigger them, to poetic expressions (Clemente 2008). A ternary conception of urban theory resurfaces constantly in Rossi's argumentations and emerges clearly in these words: "The reading of the city advanced here by primary elements, constituted urban events, and areas of influence makes it possible to study the growth of cities without the changed dimension influencing the laws of development" (Rossi 1991, 243). Primary elements, constitutive urban events, and places of influence are the three spheres of the theory of the city in parts with which Rossi reinvents the relationship between urban history and design. And later, regarding the decisive impact that architectural policy should have on urban event and the conception of the city's form, Rossi continues (Figure 8.6):

while every city possesses a personal soul made up of ancient traditions and living sentiments as well as undecided aspirations, this does not mean that it is independent of the general laws of urban dynamics. Behind the individual cases are general events, and the result is that no urban growth is spontaneous, with structural changes being explained by the natural tendencies of different groups in different parts of the city. Lastly, man is not only the man of that country and that city but is the man of a precise and delimited place and there is no urban transformation that does not also involve a transformation in the life of its inhabitants.

(Rossi 1991, 245)

The archetypes of the soul and of tripartition, with which, in my opinion, Rossi tacks together the archaeology of his poetics of urban events, open a passage from the past to the present that gives us the image of a city as a "work of art" and the result of a political idea that must be accompanied by a poetic image in order to be effective (Clemente 2016). 


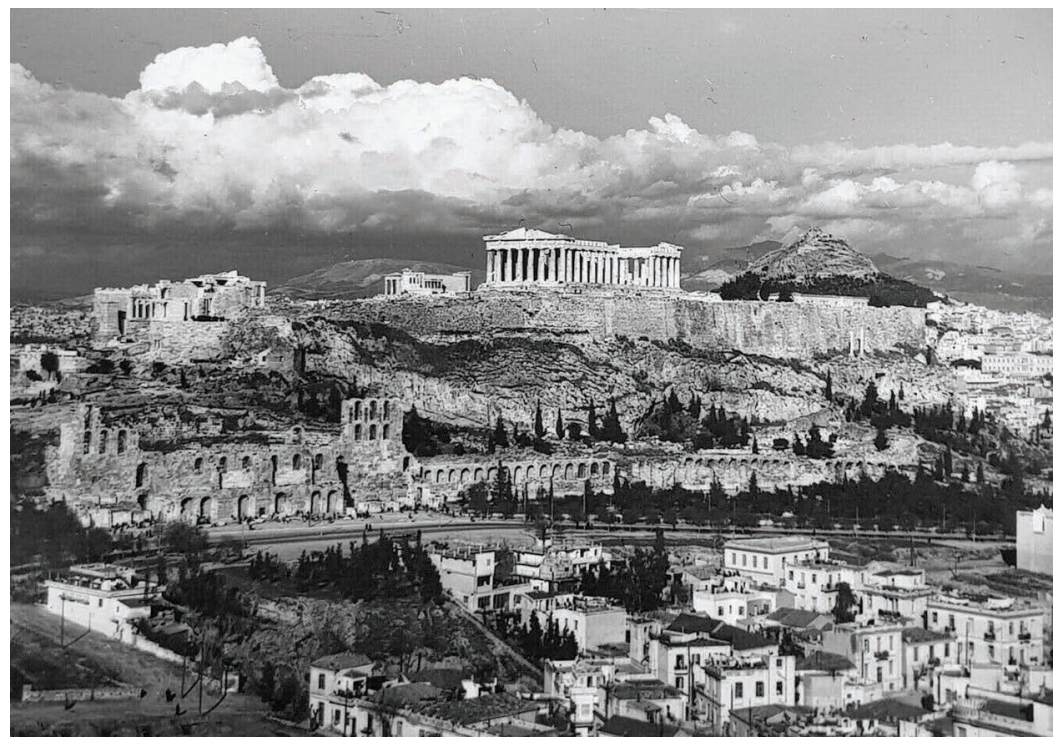

FIGURE 8.6 View of the Acropolis from the Southwest.

Aldo Rossi draws on some of the arguments used by Karl Marx in his Critique of Political Economy to deliver a powerful poetic image for the city project. Marx saw the polis and Greek art as illustrating the "childhood of humanity" (Rossi 1991, 194). Childhood is the image with which, according to Rossi, politics can become poetic, with which architecture can become poetic and so rediscover its original vocation, which is to be able to reimagine once again the invisible link between man and place as the only access to the present of the city's soul.

\section{Bibliography}

Ackerman, J. S. 1972. Palladio. Turin: Einaudi.

Aristotle. Politics 1267b, 22-37=II, VII,1-3.

Benveniste, É. 2001. La tripartizione delle funzioni. Il vocabolario delle istituzioni indoeuropee. Vol. I. Economia, parentela, società. Milan: Einaudi.

Clemente, I. 2008. Infanzia della forma. Bari: Adda editore.

Clemente, I. 2017. Twisted. La poetica di Aldo Rossi. In Aldo Rossi. Soundings, ed. L. Amistadi and I. Clemente. Florence: Aión.

Dodds, E. R. 2003. I Greci e l'irrazionale. Milan: Rizzoli.

Dumézil, G. 2017. L'ideologia tripartita degli indoeuropei. Città di Castello: il Cerchio Edizioni.

Freud, S. 1977. L'interesse per la psicoanalisi, Vol.7. Boringhieri, Turin: Boringhieri.

Greco, E. 2018. Ippodamo di Mileto. Immaginario sociale e pianificazione urbana nella Grecia classica. Paestum-Salerno: Pandemos.

Halbwachs, M. 2001. La memoria collettiva. Milan: Unicopli.

Kerényi, K. 2007. Introduction, origin and foundation in mythology. In Jung, C. G. and K. Kerényi. 2007. Prolegomeni allo studio scientifico della mitologia. Turin: Bollati Boringhieri.

Le Corbusier. 1980. Proposte di urbanistica. Bologna: Zanichelli.

Le Corbusier. 2014. La Carta di Atene. Milan: Edizioni Ghibli.

Loraux, N. 2006. La città divisa. Vicenza: Neri Pozza. 
Macchioro, V. 2014. Zagreus. Studi intorno all'orfismo. Milan: Mimesis.

Morachiello, P. 2003. La città greca. Bari: Laterza.

Patočka, J. 2019. La cura dell'anima. Naples-Salerno: Orthotes Editrice.

Piketty, T. 2020. Capitale e ideologia. Milano: La nave di Teseo.

Plato. Republic 436a-445e.

Rohde, E. 2006. Psiche. Bari: Laterza.

Rossi, A. 1991. L'architettura della città. Milan: CittàStudi.

Vernant, J-P. 2001. Mito e pensiero presso i Greci. Studi di psicologia storica. Turin: Einaudi. 